\title{
MOT EN NY VÄRLD
}

\section{Gertrud Almqvist, Margareta Suber, Karin Boye}

Detta sista kapitel handlar om tre romaner som skildrar den samkönade kärleken på ett nytt sätt. Det är Gertrud Almqvists I tolfte timmen (1928), Margareta Subers Charlie (1932) och Karin Boyes Kris (1934). Berättelserna utspelar sig i urban miljö där det råder ett yrkeskvinnoideal, där kyrkan har förlorat sitt tolkningsföreträde i sexualpolitiska frågor och där även de vetenskapliga förklaringsmodellerna ifrågasätts.

Skrivsättet i de tre romanerna skiljer sig åt väsentligt, men det finns tematiska likheter som binder dem samman. Det är svårt att beskriva det nya i positiva termer, men det kan ringas in med hjälp av en serie negationer. Den samkönade kärleken är inte ett surrogat som Nya Kvinnor tar till i brist på Nya Män (som den - delvis - är hos Stéenhoff). Den är inte bara ett ungdomssvärmeri som går över när flickan blir kvinna (som den är i en av Wahlströms romaner) och hjältinnan ändrar inte sinnelag i slutet av berättelsen (som hon gör hos Gille). Den är inte förknippad med prostitution (som den är hos Sandel) och den är inte förklädd till heterosexualitet (som den - delvis - är i Wahlströms romaner). Den är inte kopplad till synd (som den - delvis - är hos Gille). Homosexualitet skildras inte heller som något man blir förförd till. Den samkönade kärleken är inte ett brott mot naturen. I stället är den natur. Föreställningar om homosexualitet som synd, brott, narcissism, omognad, sjukdom, dekadens, degeneration, perversion, vampyrism, monstruositet och annat elände dyker visserligen upp här och var även i dessa romaner, men de reproduceras inte utan avvisas.

De berättelser som det här kapitlet handlar om öppnar dörren 
för ett mer tillåtande sätt att se på samkönad kärlek, en dörr som bara några år senare skulle slås igen i och med uppmarschen till andra världskriget. Deras livsbejakande synsätt skulle inte få någon motsvarighet i svensk litteratur förrän åtskilliga decennier senare.

\section{Gertrud Almqvist: I tolfte timmen}

Gertrud Almqvist (1875-1954) var författare och kritiker och skrev om kvinnofrågor på ett ofta humoristiskt sätt. Hon skrev bland annat i Idun och Rösträtt för kvinnor och som vi såg i kapitlet om Frida Stéenhoff var det hon som för Iduns räkning anmälde Kärlekens rival. I samma tidning anmälde hon också Lydia Wahlströms Sin fars dotter. I sin recension skrev hon:

Det är nyromantikern Lydia Wahlström, som i likhet med Fredrika Bremer upptäcker, att det finns "många andra kärlekar" i världen än den gamla vanliga mellan man och kvinna. Det är först den svärmiska flickvänskapen, en ännu så gott som outnyttjad fyndighet i litteraturen. Vilken oändligt varsam hand behövs inte för att röra vid den utan att "stoftet på fjärilsvingarna" sudlas eller förflyktigas. Lydia Wahlström har den varsamheten [...].'

Uppenbart hade hon blick för det motiv den här boken handlar om. I sin sista roman, I tolfte timmen. En gammal, dåraktig kvinnas bekännelser, återkom hon till det ännu en gång. Hon hade då en rad böcker i skilda ämnen bakom sig.

När Gertrud Almqvist presenterades som Iduns nya recensent i 1910 års första nummer nämndes det att hon hade "legat ett par terminer vid Sorbonne i Paris där de ryska studentskorna genom den beundran, de ingåfvo henne, gjorde henne till feminist, om än en mycket måttfull och afvaktande sådan”. Almqvist var skeptisk till Ellen Keys tänkande, vilket hon helt frankt berättade för Key själv i ett brev. Hon uppger där att hon arbetar med en artikel i sedlighetsfrågan. ”Det kommer att bli mycket vitt skilt från den erotiska idealismen och förmodligen att anses som om möjligt dubbelt så osedligt som denna."2 
I artikeln "Den sista gamla mamsellen" pläderade hon för att titeln "fru" skulle kunna användas av alla kvinnor över en viss ålder oavsett äktenskaplig status. Bakgrunden till förslaget var att "fru" var en statusmarkör medan ordet "fröken" var pejorativt när det användes om kvinnor som inte längre var helt unga och än mer nedsättande när det användes om ogifta mödrar:

Hvad tjänar det till, att vi med vårt förnuft intala oss och andra, att en människas innersta värde $\mathrm{i}$ intet afseende beror på om hon är fru eller fröken, att det är hennes andliga personlighet, hennes humana själslif, som värdesätta henne, och hur kan det hindra, att den ogifta kvinnan blir mindre aktad än den gifta, så länge tanklösa unga och kanske också gamla läppar med ett öfvermodigt uttryck tala om "gamla mamseller"."

Almqvist sammanfattade fördomarna mot ogifta kvinnor: "Kärleken är ändå lifvets förnämsta ändamål för kvinnan, och de som äro värdiga till den äro släktets prima vara, de andra äro affallsprodukter, och det är inte annat än riktigt, att detta betecknas genom etikett." Formuleringen är drastisk men träffande, för det fanns knappast någon nedre gräns för vad man kunde tillåta sig att säga i denna sak. Än värre var föraktet mot ogifta mödrar, något som enligt Almqvist gjorde en inkluderande titel desto viktigare:

Det finns ännu en anledning för den gemensamma titelns införande. Denna anledning är de ogifta mödrarna. Jag vet nog, att det finns människor, som anse det för sin kristliga plikt och som det högsta beviset på deras egen dygd, att de göra helvetet hett här på jorden för de ogifta mödrarna.

Hon undertecknade artikeln med "Fru Gertrud Almqvist" trots att hon då ännu levde ogift, men helt följdriktigt med tanke på artikelns innehåll.

Almqvist har hittills inte avsatt många spår i litteraturhistorien, men Kristina Fjelkestam tar med henne i sin bok Ungkarlsflickor, kamrathustrur och manhaftiga lesbianer. Hon finns med även i 
Yvonne Hirdman, Margaretha Fahlgren \& Ebba Witt-Brattströms artikel "Erotik, etik och emancipation" i Nordisk kvinnolitteraturhistoria III, men de säger underligt nog ingenting om att romanen är en av det svenska 1920-talets radikalaste texter när det gäller kärlek mellan kvinnor. I stället framställer de den helt enkelt som en (hetero)emancipationsroman bland många andra. ${ }^{4}$ I tolfte timmen publicerades under pseudonymen "Molly Molander", något som gissningsvis har att göra med dess kontroversiella innehåll.

Ironi eller cynism om - ja, vad ska jag säga ... kärlekslivet I tolfte timmen publicerades 1928, ett år som ibland har kallats för den lesbiska litteraturens genombrottsår. Inte minst i Berlin och Paris fanns det då sedan länge ett vitalt socialt och kulturellt gayliv och en gissning är att Almqvist kan ha fått inspiration därifrån.

I tolfte timmen är en märklig roman, både innehållsligt och stilistiskt. Den handlar om några vår- och sommarmånader i en medelålders kvinnas liv och den slutar med att hon går in i livets höst. Hon bär det androgynt klingande namnet Ronny. Tillsammans med en analytiker bearbetar hon sin psykosexuella utveckling från barndom till medelålder, även om hon är ytterst skeptisk till hans sätt att se på saker och ting. Samtalen med honom visar att hennes stora kärlek i livet varit en kvinna, Carla, som i ungdomen gav henne en kärlekssorg som hon sedan aldrig kom över.

Den som söker en enhetlig stil i romanen kommer att bli besviken. Större delen av den är berättad med en gycklande ton, ofta galghumoristisk eller bitskt ironisk. Man känner igen kåsörens framställningssätt i texten. Andra gånger talar berättaren utan några distanseringsmekanismer. Man kunde beskriva både romanens stil och dess innehåll på samma sätt som huvudpersonen själv beskriver den älskade Carlas sätt att uttrycka sig. "Ibland talade hon med en viss ironi eller cynism om - ja, vad ska jag säga... kärlekslivet.”' Det finns ett dubbelseende i romanen, som oftast kan avläsas som kritik mot psykoanalytikerns heterosexism och misogyni men ibland som ett problem hos Ronny själv. Hon är en främling i sitt eget liv.

I tolfte timmen är en samtidsroman och en dagboksroman. Det 
första datum som anges är 10 mars 1927, alltså året innan romanen publicerades och två år efter det att författaren själv fyllde 50 år. Den börjar med att Ronny fyller 50 och är missnöjd med att hon inte har blivit lika uppvaktad som hennes väninnor hade blivit när de fyllde jämnt. Hon säger sig ha underliga vänner, vilket hennes faster en gång förklarade med att hon själv är så underlig. Ronny tror sig inte kunna roa andra människor - "jag kan bara roa mig själv" (6) - men den roman i vilken hon är huvudperson är däremot stundtals mycket roande.

Redan från början får vi veta att Ronny inte längre delar säng med sin make, vilket hon är lättad över och han inte längre sörjer. Under många år sökte han utan större framgång sin hustrus kärlek, men numera har han sina nöjen på annat håll. Det är han som tvingar Ronny att tala med först doktor Grund och sedan med en förment mer djupanalyserande läkare. För doktor Grund berättar Ronny att hon är rädd för att åldras och han försöker trösta henne med att sexualiteten kommer att finnas kvar även efter menopausen. Det är bara det att det inte är den saken som oroar henne. "Det ger jag tusan!" Hon biter ihop om denna tanke eftersom hon förstår att doktorn inte alls skulle ha tyckt om den. "Antingen hade doktorn trott, att jag ljög, då hade han rättat sitt handlingssätt mot mig därefter eller också hade han trott, att jag talade sanning, och då hade han föraktat mig." För att göra honom nöjd intar hon i stället en min "som passar efter mottagandet av en glädjefull och oväntad bebådelse". I den värld där hon rör sig är heterosexualitet alltså ett obligatorium. Utåt sett viker hon sig för denna sexualpolitiska realitet, men i dagboken undergräver hon den med gyckel och ironi. "Men för mig själv kan jag kosta på att upprepa det: det ger jag tusan!" (10-11)

När hon slutar gå hos Grund och i stället börjar gå hos psykoanalytikern är hans första fråga om hon är lycklig med sin man. Hon svarar att hon varken är lycklig eller olycklig och att både hon och maken numera ser på sitt förhållande med humor, något hon snabbt inser att han inte tycker om. "Jag hade en bestämd känsla, att doktorn ogillade humorn." Han tror att hon längtar efter kärlek och ett nytt äktenskap: "Det har jag svårt att tro - åtminstone äkten- 
skapet, sade jag, eller tänkte jag det bara?” (14-15) När Ronny sedan berättar att hon en gång funderade på att ta livet av sig tror doktorn genast att det handlade om en man och rycker till när hon säger att det handlade om en kvinna.

I Ronnys berättelse om sin kärlek till denna kvinna, Carla, försvinner den ironiska tonen. Hon berättar rakt och enkelt om hur hon och Carla träffades å yrkets vägnar, om hur vänskapen snart blev till passion, men också om hur Carla avbröt relationen redan innan den hade hunnit gå över gränsen. Carlas kvinna kom helt enkelt hem till Ronny och gjorde slut på den. De träffades ytterligare någon gång, men då var det redan för sent och Carla alltför hårt knuten till den andra kvinnan.

Doktorn lyssnar uppmärksamt men sedan talar han i pluralis majestatis för att riktigt understryka sin auktoritet som representant för sin yrkeskår, helt i linje med språkbruket bland tidens experter. Och genast är det gycklande skrivsättet tillbaka i texten. Ronny berättar att hon tog sig en manlig älskare för att kunna leva vidare i sorgen efter Carla. "För er var han naturnödvändig", invänder analytikern, något Ronny dock är skeptisk till. (28) Men hon kan glädja doktorn med att hon som barn en gång såg en "hallelujagosse" på ett frälsningsmöte som fick henne att drömma om att han skulle slå henne.

- Ja, sedan vet jag inte mer, men doktorn vet förstås allt. Stryk, kärlek, kvinnlighet. Vad säger doktorn?

- Jag säger, att fru Berglöf haft vissa förutsättningar att utveckla sig till en normal kvinna. (40)

Formuleringen är vass och framställningssättet dråpligt. Analytikern fortsätter konversationen genom att fråga Ronny om hon brukar onanera och när hon svarar nekande förstår hon att han tycker att detta är helt fel svar.

- Jag kan inte hjälpa, sade jag, att jag inte kan leverera en provkarta på alla mänskliga laster. Jag menar, jag ber om ursäkt, för det räknas ju som rena, rama oskulden nu. Kanske är det en brist hos mig. 
Jag har så många luckor i min ... min bildning. Är det enastående, så kan ju doktorn anteckna det. (40)

Doktorn blir då så irriterad på henne att Ronny vill förklara sig. Som barn var hon ångestfylld och olycklig, men hon tror inte att det berodde på att hon var ovetande om de sexuella tingen.

Jag var ju lantbarn. Vet folk egentligen hur olika det är att vara stadsbarn och lantbarn. Lantbarn lever ju bland bönder och djur. De kan lära sig alla förvillelser, tror jag, om de har anlag utom de ensammas förvillelser. (41)

Sedan lugnar hon doktorn med att hon började känna sig lite bättre till mods när hon inledde sitt samliv med maken. Läsaren vet visserligen redan att den äktenskapliga samvaron aldrig har berett henne något större nöje, men Ronny vet att doktorn anser denna sida av livet vara avgörande. Belåtet frågar han:

- Vill ni ännu påstå att det berodde på fallet Carla?

- Nej, doktorn, men jag skulle vilja säga. Något lite berodde det på Ellen Key. Gud fröjde hennes själ i himmelriket! (41-42)

"Fallet Carla", säger doktorn föraktfullt, fastän Carla ju aldrig har varit något av hans fall. "Vill ni ännu påstå ..." frågar han som vore han en bättre vetande. Ellen Key skrivs in i Ronnys berättelse om sin psykosexuella historia på ett komiskt sätt, antagligen för att Key var känd för att i varje läge sjunga den heterosexuella kärlekens lov. Precis som analytikern.

Ronny har svårt för att ljuga, men tvingas ändå till det om och om igen. Hon måste göra det för att verka normal. För att visa att hon faktiskt är en känslig människa. Problemet är att hennes inre landskap inte alls stämmer med de gängse kvinnlighetskartorna och i den heteronormativa ordningen är det kartan, inte det inre landskapet, som gäller. När hennes dotter frågar varför föräldrarnas äktenskap ser ut som det gör undrar hon om modern kanske hade en älskare innan hon träffade fadern. Ronny vet inte hur hon 
ska svara sitt barn. Hon gör en snabb kalkyl över vad som kan vara lämpligt att säga:

"Om jag nu skulle säga sanningen", tänkte jag, "så talade jag om Carla, men då skulle inte Viveke tro, att hon finge veta min hemlighet, och när jag talar om den andre, så tror Viveke, att hon får veta sanningen, men får hon det?” (53)

Hon måste alltså ljuga för att dottern ska tro att hon talar sanning och förstå att hon faktiskt vill ge henne ett förtroende. Berättelsen om Carla skulle i dotterns ögon inte ha räckt till som Sanningen om den Stora Kärleken. Men för Ronny är den det.

Kärlek mellan kvinnor har hittills i romanen skildrats med respekt och utan några tidstypiska schabloner. Under kärlekssorgens och svartsjukans tid hade Ronny visserligen tyckt att Carlas väninna var "kantig och disgraciös" när hon mötte dem i stadens vimmel och hon hade lagt märke till de båda kvinnornas stora galoscher "som sade klafs, klafs i höstsörjan". (27) Tidigare har Carla alltid framstått som attraktiv.

När Ronny har berättat om sin ungdomskärlek för sin dotter den heterosexuella versionen - minns hon en upplevelse från sin egen barndom. Hon stod vid en mosse där man hade grävt upp en torvgrav och hon tyckte sig se ett djur nere på bottnen, ett djur som sedan flöt upp till ytan. ”Det har ett människoansikte det gräsligaste jag sett. ... det är ... det är ... mitt ansikte ..." (59) Den skrämmande kroppen, något främmande som blir besläktat, ett djurkadaver som ges mänskliga drag, väcker hennes fasa. Kanske har denna scen att göra med Ronnys förbjudna känslor, med homosexualitet, som så ofta i litteraturen hade förbundits med det monstruösa, med det låga, med dy och avskräde? Kanske är scenen mindre specifik och mer allmänt kopplad till det sökande in i det egna jaget som analysen har satt igång hos Ronny? Kanske båda?

Ronny tror att doktorn numera tror att hon är homosexuell, trots att hon "aldrig varit det riktigt handgripligt", trots att hon säger att "det var Carlas själ jag älskade" och trots att hon tror sig kunna ha älskat en man om han bara hade varit som Carla. 
[Analytikern] anser sig hos mig ha funnit en böjelse att göra mannen hans ledarställning stridig och drar därifrån konsekvensen för det erotiska specialfallet. Men o, där tar han alldeles miste. Ingen gammaldags dygde- och kvinnlighetspredikant kan med rätta förebrå mig något på den punkten. I de avgörande ögonblicken är jag passiv och viljelös, tillintetgjord som en nyslaktad lammunge. $(62-63)$

Återigen gycklar hon som synes över den tidstypiska förståelsen av sexualitet, där den kvinnliga (hetero)sexualiteten är detsamma som underkastelse under en man, som offer. Den ironiska tonen i texten är oftast som skarpast när Ronny berättar om sina heterosexuella erfarenheter och funderar över vad analytikern kan tänkas tycka om dem. Hon tänker också bakåt i tiden, tänker på sin farfar generalen och sin farmor, som var uppfostrad i Voltaires anda. Hon tänker på faderns "kvinnonerver" och mjuka, vita händer och på moderns starka, trofasta arbetshänder. Hon tänker med kärlek och respekt på sina föräldrar, som aldrig riktigt passade in i könsnormerna och inser att hon själv har fått moderns händer fast hon aldrig har utfört något handfast arbete.

Till slut ger Ronny upp sitt motstånd mot doktorn och anammar hans heteronormativa teorier. Hon tycker sig ligga vid hans fötter. "Där ligger jag nu, och där njuter jag den enda sanna kvinnolycka jag fått eller kommer att få i mitt liv och som jag med mina erotiska erfarenheter aldrig känt." (73) Om detta är sagt med ironi eller inte är svårt att säga. Ronny är tömd på allt det som legat och skavt men också på all energi. Ändå är hon lycklig, men nu tycker analytikern plötsligt att hon är alldeles för passiv.

Hon söker upp sin gamle älskare och frågar hur han uppfattade henne under deras relation. Han tror ett ögonblick att han den gången sårade henne på ett sätt som hon sedan inte kunnat komma över. "'Dåre', tänker jag, 'det var ju inte du, som förförde mig utan jag dig, och bakom allt stod Carla." (87) Hon tänker på hans allt för mjuka händer och ser på sina egna. "Vad var egentligen meningen med mina hårda, starka händer? De borde ha härskat - över vad?” (90)

Alla dessa händer som inte riktigt passar in i de stereotypa köns- 
mönstren: hennes egna, älskarens och föräldrarnas. Den verklighet som Ronny ser runt omkring sig skiljer sig helt enkelt ganska mycket från den som de vetenskapliga experterna har tecknat. Det könsöverskridande momentet hos Ronny finns också inskrivet i hennes namn, och den älskade kvinnans namn passar in i samma mönster. Här finns inte bara pojknamnet Carl inskrivet utan också ordet "karl".

En dag när Ronny länge har pratat med doktorn om sitt liv och sin misslyckade författarkarriär frågar han plötsligt om hon någonsin "nått kulmen". Hon tystnar, tvekar inför vad hon ska svara, gör återigen en snabb inre kalkyl, vet att han inte skulle tycka om att hon sa "nej" så hon säger "ja". Hon hinner också tänka att alla män är fallosdyrkare:

Det vore egentligen logiskt, om det vore kvinnan, som uppfunnit falloskulten, men jag har svårt att tro att någon kvinna vid förnuft och eftertanke, och det är det väl också tillåtet att ha i mellanakterna, ansett den där saken för något annat än ett enkelt, ändamålsenligt och nyttigt redskap. (98)

Så tänker hon, men hon säger något helt annat. Några veckor senare kommer hon fram till att doktorn trots allt kanske inte är någon fallosdyrkare och nu håller hon plötsligt med honom om sexualitetens grundläggande betydelse, men mer som livskraft, som religion än som en serie praktiska (hetero)bestyr. När hon tänker så släpper den ångest hon har burit med sig genom livet och hon börjar kunna ta till sig livets enkla glädjeämnen - en katt, utsikten från balkongen, en väninna som hon tidigare känt sig främmande inför. Hon börjar till och med tänka på maken med lite större tillgivenhet.

Jag sade nyligen till doktorn, att jag inte bryr mig om, om jag är homosexuell eller inte eller om jag varit det snarare, för det var ändå bara "faute de mieux". Jag har en vän, som säger, att det är kor också av samma grund. [...] Jag skulle gärna vilja tro henne, för det är verkligen roligt att inte vara onaturligare än en ko. (154) 
Ett slags försvar för den samkönade sexualiteten, kunde man säga, formulerat med drastisk humor. Hur Ronny har kommit fram till att hon bara älskade Carla i-brist-på-bättre får läsaren aldrig veta. Det bara sägs. Plötsligt och utan egentlig grund i berättelsen är allting förändrat och hon har införlivat doktorns verklighetsbild. Han säger vid deras sista möte att om Ronny någonsin har älskat en man, så är det maken. Hon hör på utan att protestera och funderar på om hon inte trots allt skulle kunna finna sig bättre till rätta med maken. Hon inser att det var när hon började kritisera honom som konstnär som han började skälla och domdera. Kanske hade han blivit en stor målare om hon hade varit mer stöttande. Men säker är hon inte.

Kommen så långt i sina tankar nås hon av två brev: ett från maken där han skriver att han har funnit en ny kvinna och ett från dottern som skriver att hon har funnit Gud. Ronny har i ett slag blivit ensam. Doktorns "kur" har hjälpt henne att bekämpa sin livsrädsla, men när hon nu vill tillämpa sina insikter i det egna familjelivet finns det inte längre någon familj att tillämpa dem på. De relationer hon har haft genom livet passerar revy och hon tycker att hon aldrig har varit trofast mot någon. Men den berättelse där hon är huvudperson säger något annat.

\section{Inte onaturligare än en ko}

Ronny har en kritisk dubbelblick på tillvaron och en ironisk distans till psykoanalysens androcentrism och heteronormativitet. Hon analyserar den rådande könsmaktsordningen samtidigt som hon underminerar den genom sitt gyckel. Ändå är hon en fånge i den rådande ordningen utan förhoppningar om ett annat och lyckligare liv.

I tolfte timmen handlar om en kvinna som är 50 år, en ålder då kvinnor enligt de gängse värderingarna har förlorat sitt erotiska marknadsvärde. Ronny ser sig själv som värdelös och löjlig men finner däremot inget löjligt $i$ att hennes make, som är äldre än hon, tar sig en ny ung hustru. Ronny analyserar och häcklar den ojämlika köns- och sexualitetsordningen, men nedvärderingen av äldre kvinnor framställs närmast som naturgiven. Mot åldrandet biter 
inte gycklet. "Det verkliga livet får man nog dras med själv." (171) Komedin har blivit tragedi.

I sin anmälan av Frida Stéenhoffs Kärlekens rival skrev Almqvist att samkönad kärlek inte är ett ämne för socialreformatorer eller litteratörer, utan för psykiatriker, men hon måste ha ändrat uppfattning ordentligt med tanke på hur den här romanen häcklar de medicinska och psykoanalytiska teorierna om sexualitet, liksom läkarnas tolkningsföreträde i dessa frågor. Det finns ett gap mellan deras verklighetsbilder och den erfarenhetsvärld som Ronny berättar om i sin dagbok och det är i detta spänningsfält som gycklet får sin kraft.

I slutet av romanen kapitulerar Ronny inför analytikerns idé om att kärlek mellan kvinnor är ett surrogat för heterosexualiteten, men den känslomässiga verklighet som stiger fram ur texten är en annan. "O, Carla..." lyder de sista orden i dagboken. Och i romanen. Att den älskades namn får utgöra romanens allra sista ord gör det tydligt att känslorna för Carla har spelat en avgörande roll i Ronnys liv. Fredrika Bremer använde samma knep i romanen Hertha (1856), där den allra sista meningen lyder: "Hon gifte sig aldrig, och hennes enda jordiska kärlek var - Hertha." Och Almqvist hade ju sin Bremer. Världen må tycka och tänka vad den vill, men det är den samkönade kärleken som är den viktiga.

\section{Margareta Suber: Charlie}

Margareta Suber (1892-1984) är en författare med en ovanligt lång verklista. Förutom romaner skrev hon barnböcker, reseböcker och noveller och dessutom gjorde hon en hel del översättningar. Den av hennes böcker som varit mest uppmärksammad på senare år är just Charlie. Ibland har den kallats för den första svenska lesbiska romanen, något som vi sett inte är riktigt sant. Men inte heller direkt fel. Berättelsen handlar om en ung kvinna som kommer till insikt om sin känslomässiga beskaffenhet. Det är något så ovanligt i svensk litteratur som en lesbisk komma-ut-historia. ${ }^{6}$

Charlie är uppenbart influerad av Radclyffe Halls skandalsuccé The Well of Loneliness (1928), som fälldes för obscenitet trots att det 
närmaste berättelsen kommer en sexskildring är orden "and that night, they were not divided". Domen var tänkt att förhindra att romanen blev läst men kom att motverka sina syften - den blev startsignalen för debatter och stödkampanjer som tillsammans utgjorde en mycket effektiv reklam för boken. Att den var bannlyst i England hindrade ju inte att den publicerades i andra länder och översattes till andra språk. På svenska kom den 1932.

Det måste ha varit det radikala sexualpolitiska perspektivet $\mathrm{i}$ The Well of Loneliness som oroade, för det finns ingenting av erotisk spekulation i romanen. Kanske var det rentav just därför den väckte uppseende. Erotik mellan kvinnor hade skildrats förr, inte minst inom pornografin, men den hade då serverats för heteromanliga konsumenter. Samma sak brukade hända i skönlitteraturen. Äldre exempel från fransk litteratur hittar man i Théophile Gautiers $M a-$ demoiselle de Maupin (1835) och Emile Zolas Nana (1880). Ett med Radclyffe Hall mer samtida exempel är Victor Marguerittes storsäljare La Garçonne (1922), en roman som kom på svenska redan året därpå under titeln Ungkarlsflickan. Här berättas om crossdressing och utstuderade kreationer, om droger och genomfestade nätter, om sex av såväl sam- som olikkönat slag. Men heteronormen bekräftas genom det voyeuristiska perspektivet. De samkönade relationerna framstår som uttryck för excess och självdestruktivitet snarare än för erotiskt begär.

Det fanns också andra sätt att se till att kvinnokärleken inte kom i konflikt med normen om heterosexualitet och manligt tolkningsföreträde, exempelvis aggressivitet och våld. D. H. Lawrence berättar i The Fox (1923) om hur en man bryter sig in i en relation mellan två kvinnor, lägger beslag på den ena för eget bruk och sedan kuvar dem båda. Tidigare hade Henry James i The Bostonians (1886) och August Strindberg i Giftasnovellen "Ett dockhem" (1884) berättat liknande historier. Tanken att det existerar kvinnor som inte blir förälskade i män, ja som inte ens hatar män, utan helt enkelt bara blir attraherade av kvinnor, tycks ha varit chockerande.

Även The Well of Loneliness slutar med att den ena kvinnan gifter sig, men det sker inte för att mannen och heterosexualiteten skulle vara överlägsen kvinnan och homosexualiteten - det är huvudper- 
sonen själv som föser sin älskade i famnen på mannen för att hon ska slippa leva med den marginalisering som var den samkönade kärlekens existensvillkor. Berättelsen ses ur Stephens, avvikarens, perspektiv och beskriver den heteronormativa ordningen som förtryckande och irrationell.

Margareta Subers Charlie är som sagt skriven i Halls efterföljd, men en gissning är att den också hade hämtat influenser från tysk litteratur och mentalitet. Berlin var ju en metropol för gaykulturen vid den här tiden och det var här som Magnus Hirschfeld verkade. Tysk litteratur kunde uppvisa åtskilliga romaner med lesbiskt tema, som Der Skorpion (1919-1931) av Anna E. Weirauch och Freundinnen (1924) av Maximiliane Ackers. Båda handlar om en hastigt uppblossande passion som snart fullbordas sexuellt, utan att den yngre kvinnan förstår att detta är något som kyrkan, vetenskapen och resten av samhället finner oacceptabelt. Kvinnorna uppfattar sina känslor som naturgivna och det är först efter ett tag som de inser att de är ensamma om att uppfatta saken så. Båda kärlekshistorierna slutar olyckligt, men huvudpersonerna ger inte upp utan accepterar sina känslor och går vidare i livet.

Berlin var också staden där man satte upp en teaterpjäs med lesbiskt tema, nämligen Christa Winsloes Gestern und heute. Författaren och kritikern Hagar Olsson var i Berlin för Tidevarvets räkning vid den här tiden och under rubriken "Kvinnlig teaterseger i Berlin" skrev hon en entusiastisk recension av föreställningen. Olsson börjar med att klaga över idétorka i Berlins teaterliv, för att sedan belåtet lyfta fram Winsloes pjäs, där enbart kvinnor står på scenen, som något nytt och spännande. ${ }^{7} 1935$ sattes pjäsen upp på Blancheteatern i Stockholm under namnet Flicka i uniform, med den debuterande Signe Hasso i huvudrollen..$^{\mathrm{b}}$ Pjäsen låg sedan till grund för filmen Mädchen in Uniform (1931) av Leontine Sagan, en film som belönades med flera stora priser och visades i åtskilliga länder. Den har kallats för den första kvinnofilmen, även om en och annan man var inblandad i produktionen. Filmen hade en kvinnlig regissör, en kvinnlig manusförfattare och enbart kvinnliga skådespelare, och handlar om olika slags relationer mellan kvinnor på en internatskola där målet är att forma flickorna till soldatmödrar. Männen och det 
preussiskt maskulina finns inskrivna i arkitekturen och i statyer av krigsherrar och stridande mansgestalter filmade underifrån så att de framstår som jättar. Det krigiska begränsar flickornas rörelsefrihet. Det sjuder av känslor mellan eleverna och mellan flickorna och en av de kvinnliga lärarna. I pjäsversionen är det lesbiska temat mer uttalat och det hela slutar tragiskt, men i filmen gör flickorna uppror och räddar Manuela, som huvudpersonen heter. Visserligen avvisas hon av den älskade läraren, men filmen visar att kärleken trots det är ömsesidig. Läraren protesterar när rektorn talar om den som ett brott som måste bestraffas. Filmen slutar med att den iskallt auktoritära rektorn går ned för en trappa och ut ur bilden. Hennes makt är bruten. Solidariteten i flickkollektivet har segrat.

Men tillbaka till Charlie och The Well of Loneliness. Det finns många likheter mellan Subers och Halls romaner, till exempel den att den sexologiska diskussionen explicit lyfts in i båda romanerna. I The Well of Loneliness är det Richard von Krafft-Ebing som öppnar huvudpersonens ögon för hurdan hon själv är medan det i Charlie i stället är Otto Weininger som fyller den funktionen. Weininger var populär bland det tidiga 1900-talets antifeminister samtidigt som han väckte intresse på flera håll inom kvinnorörelsen, eftersom han beskriver kvinnligt och manligt som punkter på en glidande skala snarare än som två väsensskilda storheter. Weininger såg bisexualitet och könsöverskridande som en del av det mänskliga normaltillståndet, inte som något ytterligt och spektakulärt. Arnold Sölvén hade gett honom förnyad aktualitet i den litterära debatten genom Kätterier $i$ kvinnofrågan där han gick till storms mot kvinnorörelsen, som han satte i samband med kvinnlig homosexualitet. ${ }^{8}$ Men Charlie är en lättare och ljusare berättelse än The Well of Loneliness, både vad gäller skrivsättet och innehållet. Karin Boye berömde Charlie för dess "fulländade stil, ovanlig inte bara för en debutant" och menar att den väckte kritikens beundran. ${ }^{9}$

Charlie "vet" inte hur hon själv är beskaffad förrän hon bläddrar i Weiningers Geschlecht und Character (1903) och det gör inte personerna i hennes omgivning heller. Boken har smusslats ner i hennes strandkorg av någon okänd. När Charlie bläddrar i boken "förstår" hon att hon är annorlunda och känner sig förnedrad av 
att en anonym person har sett detta och nu försöker näpsa henne genom att smuggla in den obehagliga boken bland hennes saker. Det hela blir en parallell till en händelse som Charlie var med om som barn och som då hade berört henne illa. En jämnårig pojke skickade pornografiska bilder till henne, som en hämnd för att hon hade klått upp honom. (Han hade förtjänat det.) Sexuella trakasserier är inget nytt påfund.

Romanens händelser utspelar sig på en fashionabel badort, där internationellt orienterade människor lapar sol på dagarna och roar sig tillsammans på kvällar och nätter. Där finns en baron och en halvdan konstnär, där finns en landsflyktig rysk ballerina och en gammal överste. Stressade affärsmän kommer ut till sina familjer på helgerna och ibland flygs grupper av badgäster ut till stränderna på kortare visiter. En jazzorkester pumpar upp stämningen på dansgolvet, man dricker groggar, röker cigaretter, talar om psykoanalys och har sexuella förbindelser. Det är det glada tjugotalet.

I centrum för händelserna står Charlie, som blir förälskad i den unga änkan Sara, en kärlek som dock inte besvaras. Eller gör den det? Berättelsens slut öppnar för båda möjligheterna. Som barn var Charlie en pojkflicka och nu håller hon på att mogna till en kvinnoälskande vuxen kvinna. Hon har smala höfter, breda axlar och en kort frisyr, precis som Stephen i The Well of Loneliness, men hennes kinder är flickaktigt runda. Hon klär sig androgynt, känner sig förnedrad när hon tvingas bära alltför "kvinnliga" kläder men ledig när hon går klädd i "en svart kinesisk sidenpyjamas med en liten låg, uppstående krage". ${ }^{10}$ Hon har till och med en "manligt" skuren aftonklänning, vad nu det kan tänkas innebära. Hon är sportig, gladlynt och full av upptåg, hon har moderna tekniska prylar som kamera och resegrammofon och älskar att fara fram längs slingriga vägar i sin röda sportbil. Hon är en typisk garçonne.

Läsningen av Weiningers bok får Charlie att börja analysera sig själv och sina känslor för Sara. Hon kommer fram till att hon faktiskt är annorlunda, att hon är homosexuell, och inser att hon därmed riskerar att drabbas av förakt. Men det leder också till acceptans och förändring. "Då vet jag i alla fall nu, att jag älskar dig, Sara, viskade hon, och du är hundra gånger mer värd att älskas än någon annan." 
(98) Charlie kanske inte är som andra kvinnor, men hon finner de grundstenar hon behöver för att bygga en framtid och hennes känslor är kanske inte så helt utan social relevans som hon under några ångestfulla sommarveckor först trodde.

\section{Ett välklingande ackord}

Charlies kärlek till Sara är berättelsens centrum, men runt detta finns andra berättelsefragment om samkönad kärlek som får den att framstå som mindre ensam i sitt slag, som mera vardagsnära. Saras dotter avgudar Charlie. Hennes känslor är så starka att Sara blir bekymrad; hon tolkar dem som förälskelse och tycker att hon på något sätt måste skydda dottern. "Vad utövade Charlie för dragningskraft på den halvvuxna flickan?" (80)

Sara anställer en lärarinna, en fröken Thilt, som ska hjälpa barnen med matematik. "Hon var ganska liten till växten, magerlagd och med slätkammat hår och platt byst." (127) Charlie ser uppmärksamt på den främmande kvinnan, tycker att hon är väsensskild från Sara, men däremot ganska lik henne själv, fast i en äldre tappning:

Det berörde henne obehagligt att finna en likhet mellan sig själv och en människa, som uppenbarligen alltid måste förbli Sara främmande. Dessutom stöttes hennes ungdom tillbaka av den andras grå medelålder, av det barskt snöpta könslivet, som knappast lämnat några spår av att någonsin ha existerat. Men framför allt värjde hon sig mot intrycket av likart med ett väsen, som stod totalt avsnört från Sara, livet ... (127-128)

Charlies blick på den andra är skoningslös, för att inte säga homofob. Detaljen om "det barskt snöpta könslivet" hör definitivt hemma bland tidens antifeministiska och antilesbiska klichéer. Författarens val av namn åt henne pekar i samma riktning: "tilta" betyder som verb "luta", "vicka" och som substantiv "jordremsa som vid plöjning vänds" och kan alltså associeras med begrepp som "inversion", "perversion" och "konträr" som alla har sin grund i tanken att könet och sexualiteten på något sätt har kastats om. Denna tanke var, som 
redan konstaterats flera gånger, frekvent i tidens homofoba diskurser. ${ }^{11}$ Men Charlie ser också att hon har "en stadig blick" och "ett par kloka, grå ögon". Hon kanske inte är så sexig, men hon är i alla fall en bra människa.

Några sidor längre fram dyker ännu en kvinna upp som kan kopplas till samkönat begär. "En fyllig dam med pincené gled ett ögonblick med blicken över Charlie men utan att se henne." (140) Blicken som sveper över kroppen och pincenén ingår i den kvinnliga homosexualismens associationssfär.

Men den viktigaste berättelsen om kärlek mellan kvinnor får Charlie höra av sin väninna, en rysk dansös, som berättar om en flicka hon lärde känna när hon själv en gång var mycket olycklig:

- Vad var det med henne, med Ninja?

- Hon liknade dig.

- Liknade hon mig? På vad sätt?

- Låg jag ensam och grät av hemlängtan om kvällarna, så blev jag lugn, när hon kom in. Och sedan hittade hon på att lägga sig bredvid mig i min säng, och hon smekte mig. Hennes händer liknade dina och hennes röst också. Jag har tänkt på det många gånger. (146)

Charlie lyssnar till sin väns berättelse med bultande hjärta. Detta är ju en berättelse om en kvinna som älskar en kvinna och där kärleken faktiskt besvaras. "Har du saknat henne?" frågar Charlie, utan att våga se på vännen. "Ja, alltsedan jag lämnade Ryssland." Charlie tar emot berättelsen med spänt intresse och läser sedan in sin egen historia i den.

När vännen gått ligger Charlie och bläddrar i ett fotoalbum med bilder enbart på Sara. Minnen av några lyckliga, gemensamma sommarveckor, drömmar om en gemensam framtid. Sara har hastigt lämnat badorten - för att hon inte längre vågade stanna kvar, för att hon inte kunde hantera Charlies känslor, men kanske också för att hon inte längre var säker på att hon kunde hantera sina egna.

Charlie gick tidigt till sängs och låg och bläddrade i ett litet album 
med amatörfotografier. De föreställde alla Sara. Hon lade det under huvudkudden, släckte sin lampa och föll i en djup, sund sömn. Lakansspetsen höjde och sänkte sig med hennes jämna, långa andetag. Hon hämtade nya krafter i ungdomens helhjärtade, obrutna vila, som fullbordar det som växer.

Hennes kropp var nu mogen att börja leva det liv, för vilket vår Herre behagat skapa henne. (149)

Charlie har inte mycket gemensamt med de drogade, blaserade, halvmonstruösa, mer eller mindre sjuka och brottsliga kvinnor som så ofta hade fått representera den kvinnoälskande kvinnan i litteraturen. Hon är förknippad med ungdom, livsglädje, sportighet och modernitet. "Hon var som ett välklingande ackord, spelat av en nyck av vår Herre. Skorrande och falska blevo tonerna först under människohand." (87)

\section{Karin Boye: Kris}

Karin Boye (1900-1941) är en av mycket få svenska författare från första halvan av 1900-talet som öppet förknippas med samkönad kärlek, trots att så många engagerade sig för den både i liv och dikt. En förklaring kan nog sökas i Margit Abenius biografi om Boye, Drabbad av renhet (1950), som under många år präglade bilden av henne. Abenius skriver fram något hon kallar "den mörka gåtan" hos Boye och som handlar om dödsdrift och förbjudna erotiska begär. Att förbinda homosexualitet med självdestruktivitet och dödsdrift har varit en återkommande kliché. Långt, långt in på 1900-talet har berättelser om homosexuella antingen skildrat dem som allmänt missanpassade, eller, om karaktärsegenskaperna har rymts inom det mänskliga normalspannet, slutat med galenskap, självmord eller med en återgång till den heteronormativa ordningen. Ett bra homo är ett dött homo. Den bild av Boye som Abenius skriver fram passar sorgligt nog in i det mönstret. ${ }^{12}$

Men att Boye har förknippats med samkönad kärlek har givetvis också att göra med det hon faktiskt skrev. Hennes kärleksdikter riktas för det mesta till ett könsneutralt "du" och borde därför inte 
kunna placeras in i dikotomin homo-/heterosexualitet, men eftersom andra författare, de heterosexuella, så gärna lägger in könsmarkörer i sina texter har det könsneutrala i praktiken ofta kommit att fungera som en markör för det förbjudna.

Som kritiker skrev Boye gärna om texter med homomotiv. En särskilt viktig text var det redan uppmärksammade inlägget i Krusenstjernafejden där hon kritiserade den homofoba kritiken, samtidigt som hon påtalade fördomar även i Krusenstjernas egna texter. ${ }^{13}$ Hon arbetade då själv med motivet samkönad kärlek. "Karin Boye var extremt välinformerad om sexologi. Hon hade läst alla sju band av 'Studies in the Psychology of Sex' av Havelock Ellis", berättar Ebbe Linde. ${ }^{14}$ En imponerande prestation, som skvallrar om hur viktigt ämnet måste ha varit för henne.

I Kris (1934) skapade hon ett nytt formspråk för att skriva om samkönat begär utan att reproducera några heteronormativa tankefigurer. ${ }^{15}$ Det var, som Abenius skriver, en hjärtesak för Boye att skriva denna roman. Ämnet hade mognat för henne genom egna erfarenheter, genom samtal med likasinnade och (kanske) genom den psykoanalys hon hade genomgått. En vistelse i Berlin hade varit en vändpunkt. Då blev hon närmare bekant med gaykulturen, då träffade hon Margot Hanel, den kvinna som skulle bli hennes livskamrat, och då kunde hon acceptera sin egen känslomässiga konstitution.

Kris publicerades året efter det att Vilhelm Lundstedt hade lämnat in sin motion om homosexualitetens avkriminalisering och Gunnar Nycander hade publicerat En sjukdom som bestraffas, där han skriver att homosexualiteten "är för individen själv och för samhället i övrigt en icke önskvärd sjukdom eller abnormitet och bör såsom sådan bekämpas". ${ }^{16}$ Brott eller sjukdom? Vilket kan tänkas ha varit svårast att leva med?

Kris tillkom när striden om Krusenstjernas Pahlensvit pågick som värst. En del andra romaner med samkönade motiv hade också publicerats. Ämnet var glödhett. 


\section{Abenius bild av Boye}

Eftersom Abenius biografi så länge har dominerat bilden av Boye och fortfarande är aktuell ska vi dröja lite vid den. Abenius varvar berättelsen om Boyes liv med läsningar av de litterära texterna och inte så sällan anger hon - som kände Boye - den personliga bakgrunden till dem, ja till och med vem olika kärleksdikter är riktade till. Hur hon nu kunde veta allt detta och hur hon nu kunde tro att författaren arbetade på det viset. Själv värjde sig Boye för det biografiska sättet att förstå hennes skapande. Hennes dikt var något annat än personlig bikt. Abenius menar att "den mörka gåtan" kan förklara det splittrade och självdestruktiva i Boyes väsen. Boyes homosexualitet beskrivs som en avvikelse, som sjukdomsframkallande och som en förklaring till hennes allt för tidiga död. För detta har Abenius på senare år blivit rejält ifrågasatt. Kritikerna menar att det splittrade hos Boye inte ska sökas i den känslomässiga konstitutionen utan i det faktum att hon levde i ett homofobt samhälle som inte tolererade hennes kärlek. ${ }^{17}$

Men kritiken mot Abenius är kanske inte helt och hållet rättvis, för hon ger trots allt det förbjudna ganska stor uppmärksamhet, något som inte tillhörde vanligheterna under bokens tillkomsttid. ${ }^{18}$ Fanns det minsta möjlighet att heterosexualisera en beundrad författare så grep man efter den och fanns det ingen kunde man ju alltid hitta på en. Historierna om Sapfo från Lesbos rymmer exempel på en häpnadsväckande uppfinningsrikedom i denna väg. ${ }^{19}$ Men Abenius valde inte den vägen. I stället synliggjorde hon den personliga och politiska radikalism som fanns hos Boye och andra under mellankrigstiden, trots att vindarna hade vänt när Abenius påbörjade boken och trots att det sexualpolitiska klimatet hade hunnit bli bottenfruset när hon publicerade den. Abenius är ambivalent inför homosexualiteten på ett sätt som (förhoppningsvis) framstår som oacceptabelt idag, men kanske var det svårt att gå längre än hon gjorde den gången. Frågan är om det över huvud taget finns någon text i det litterära Sverige från tidigt 1950-tal som tar upp samkönad kärlek på ett mindre fördomsfullt sätt än Abenius gjorde. Hennes sätt att marginalisera homosexualiteten är jämförelsevis - men bara 
jämförelsevis - beskedligt. Det finns grader i det homofobiska helvetet.

Abenius utgår från auktoriteter som Havelock Ellis och Sigmund Freud när hon försöker förstå det samkönade begäret. Hon söker förklaringar i såväl genetiska faktorer som i barndomsupplevelser och fyller sedan på med tankar, händelser och relationer under ungdomen. Men Abenius ger också uttryck för en viss skepsis mot det sexologiska idiomet. När hon introducerar det homosexuella temat lägger hon in en intressant parentes:

(Ordet homosexualitet kommer en och annan gång att användas i biografien, såsom terminus tecnicus; det sker dock i klar insikt om att termer, använda på mänskliga sammanhang, alltid är förgrovande och just därigenom ofta missvisande. För övrigt torde bisexualitet i detta fall vara en mer adekvat term. $)^{20}$

Abenius tar till ordet "bisexualitet" för att mildra det intryck som det "förgrovande" ordet "homosexualitet" kan tänkas ge. Precis som Wahlström och andra tycks hon uppfatta beteckningen "bisexualitet" som mindre belastande. I tidens psykologiska litteratur hette det ofta att bisexualitet ingår i alla människors känslomässiga repertoar. Men om man trollar bort homosexualiteten genom att omvandla den till bisexualitet, varför ser man då samkönad kärlek som ett sådant jätteproblem?

Abenius kommenterar också Boyes iscensättning av kvinnlighet. Hon lyfter fram en del könspolitiska faktorer som förklarar varför Boye och många andra inte alltid betedde sig fullt så "kvinnligt" som omgivningen ansåg att de borde göra.

Hon hade i hög grad vad psykologerna kallar "den manliga protesten", det vill säga trots mot kvinnorollen sådan den utformats av kulturen, en kultur som drivit bort kvinnorna från hennes [sic] ursprungliga uppgifter men ändå inte godtagit henne i nya och som kallar alla stolta, starka och värdefulla dygder manliga och överlämnar endast underkastelse och svaghet åt kvinnan. ${ }^{21}$ 
Någon gång snuddar Abenius till och med vid tanken att det var homofobin snarare än homosexualiteten som var det stora problemet för Boye. Hon återger fundersamt något som Boye själv hade sagt till henne om en gemensam bekant. Boye hade sagt att denna kvinna "var den enda heterosexuella människa, inför vilken hon inte kände sig olik andra och hämmades av tanken på detta". Abenius kommenterar: "Om det var så, är det verkligen både skakande och tänkvärt och visar under vilket tryck hon levde." ${ }^{22} \mathrm{Ja}$, det gör ju det. Om denna insikt hade genomsyrat biografin hade den sett annorlunda ut.

Abenius menar att Boye försökte komma över de förbjudna känslorna dels genom relationer med män, dels genom psykoanalys. "Det torde inte vara något tvivel om att Karin Boye under denna tid med en viktig del av sitt jag önskade bli riktig och vanlig eller, som det trista ordet lyder, normal." Att hon misslyckades med detta förklarar Abenius med "den mörka gåtan" i kombination med att Boye aldrig träffade Den Rätte. ${ }^{23}$ Men hon lyfter ändå upp den sexualpolitiska stridsviljan hos Boye och kallar Kris för både en debattroman och en självbiografisk roman:
"Kris" var hjärtesak alltigenom för henne. Omkring 1933 diskute- rades en humanisering av lagarna mot avvikande sexualitet. Karin Boye tog del av dem och opponerade sig bland annat mot beteck- ningen "sjukdom" i sammanhanget. Som sjuk uppfattade hon sig inte. Efter Berlin kände hon sig ha fătt en viss överblick över sitt läge. Hon drömde om att skildra sin ungdoms betydelsefulla kris och därigenom själv få framträda med öppet visir. Och kanske skulle hon någon gång $\mathrm{i}$ framtiden få kraft och möjlighet att slå ett slag för olyckskamrater som hotades av uteslutning ur levande mänsklig gemenskap. ${ }^{24}$

Men det finns en sida i Abenius bok som knappast kan försvaras hur man än ser på saken och det är den bild hon ger av Margot Hanel, Boyes sambo och livskamrat under många år. De träffades i Berlin 1932. Abenius återger en lång passage ur ett brev där Boye berättar om de officiella bekantskaper hon gjort i Berlin men också om andra, mer spännande möten: 
(Jag har nämligen också gjort en del oofficiella under diverse ensliga strövtåg i den undre världen. De är ofta lika fängslande. Särskilt har jag gjort bekantskap med en liten atenska, som jag hittade som gigolo på en mindre väl känd damklubb ... En typ, som jag aldrig förr har sett maken till, en lustig och värdig liten person, pessimistisk och slyngelaktig, går alltid i pojkkläder. Det här får du inte tala om, det är inte passande. $)^{25}$

Så långt allt väl. Om "den lilla atenskan" har lånat drag av Hanel eller inte får vara osagt. När Abenius sedan beskriver Margot Hanels familjehistoria sker det på ett sätt som inte bara är homofobiskt utan också antisemitiskt. I första upplagan av biografin beskrev hon Hanel som "en berlinsk borgarflicka av blandtyp mellan en judisk mor och en tysk far, där alla de fyra barnen visade spår av sexuell inversion". ${ }^{26}$ Att icke önskvärda egenskaper - som homosexualitet ofta var resultatet av "rasblandning" var en nazistisk älsklingstanke som går tillbaka på såväl rasbiologiska som sexologiska teorier. Det antisemitiska momentet i formuleringen mildrades i andra upplagan efter kritik från Kaj Bonnier, men en rejäl rest återstod och det homofobiska ändrades inte alls. Hanels homosexualitet görs ärftlig och medfödd, medan Boyes görs förvärvad, och de värderas därefter. Abenius vidareför klichén om de "ärftligt homosexuella" som en samhällsfara som förförde "normala" till att bli homosexuella. De förvärvat homosexuella ansågs vara mer oförargliga. Abenius fortsätter sin karaktäristik av Hanel:

Vid en flyktig bekantskap såg hon ut att vara en intellektuell typ, men i själva verket var hon inte intellektuell och inte heller intelligent, hade överhuvudtaget inga andliga resurser som ens tillnärmelsevis gick upp mot Karin Boyes. Men hon var mäktig en hel känsla och fäste sig från början vid Karin Boye med en stor kärlek, vari ingick både en svartsjuk dyrkan och beundran över alla gränser och ett barns hjälplöst vädjande ömhetsbehov. Karin Boyes känsla för henne var väl från början av mera ytligt sensuell natur, fast moderlig ömhet säkerligen redan nu spelade in. ${ }^{27}$ 
Hårdare ord om en författarhustru får man leta efter. Hanel framställs som ointelligent, efterhängsen och svartsjuk och tilldelas inga andra goda egenskaper än de att hon nog var hederlig och älskade Boye. Det faktum att hon som tysk judinna var ytterligt utsatt under nazitiden och att vägen tillbaka till Tyskland var stängd för henne mildrar inte talet om osjälvständighet. Det faktum att Hanel en månad efter Boyes bortgång frivilligt följde den älskade i döden lockar inte fram några stora ord. Att hon inte fanns med i Boyes dödsannons, inte fick gå närmast kistan, inte satt bland de närmast sörjande på begravningen och inte var med när familj och vänner samlades efteråt föranleder inga kritiska ord om hur hon blev behandlad. Inte ens det faktum att Boyes mor krävde att få de brev och dikter som dottern hade skrivit till Hanel för att sedan förstöra dem får Abenius att reagera nämnvärt.

"Det har väl hos en del bedömare kunnat spåras en tendens att göra Margot Hanel till syndabock för att något blev skevt i Karin Boyes liv", skriver Abenius, till synes omedveten om vad det är hon själv gör. ${ }^{28}$ Hennes bild av relationen mellan Boye och Hanel reproducerar idén om medfödd respektive förvärvad homosexualitet, där Hanel är den "skyldiga", men också, inkonsekvent nog, idén om mor/dotterförhållande där modern, i det här fallet Boye, brukar göras till den mest "skyldiga". Vid något tillfälle snuddar hon också vid tanken att "avvikelserna" hos Boye har att göra med överkultur, alltså ännu en klichéföreställning - kulturens dekadens leder till naturens pervertering. ${ }^{29}$

Abenius var jämngammal med Karin Boye. De lärde känna varandra under studenttiden och behöll sedan kontakten. De föreställningar hon reproducerar ger en bild av hur människor i Boyes närmaste (hetero)omgivning kunde se på samkönad kärlek, det vill säga moderna unga människor som var kritiska till moralkonservatismen. I övrigt dominerades samhället av mer eller mindre öppen homofobi.

Hur samtalen såg ut i den krets av "kvinnliga bohemer" som Boye träffade i det stockholmska restauranglivet - jag tolkar det som att Abenius här menar kvinnoälskande kvinnor - är svårare att veta något om. Den historien är ännu inte berättad. Abenius talar 
om dem som "folk som ansåg sig vara i samma båt" och beklagar att Boye umgicks så mycket med dem. ${ }^{30}$ Men dessa färdkamrater var troligen helt nödvändiga för att Boye skulle kunna utmana tidens homofoba föreställningar på det sätt hon faktiskt gjorde.

\section{Vi måste anförtro oss åt vår längtan}

Kris är en mångfacetterad text som handlar lika mycket om konst och skapande som om sexualitet och jagtillblivelse. Berättelsen börjar med att den unga Malin Forst sitter i lärarseminariets bönsal den första dagen på den nya terminen. Hennes tankar kretsar kring andliga frågor. Hon är fångad i en auktoritär tro och ber om kraft att lämna alla personliga önskningar bakom sig för att i stället bli ett självutgivande redskap för Gud. "Detta var Malin Forst, tjugu år." ${ }^{11}$

Vi får följa Malins utveckling under ett år på seminariet och hur hon hänsynslöst piskar sig själv framåt i studierna. Lärarna är nöjda med hennes prestationer, men i sina egna ögon är hon aldrig bra nog. "Bed och arbeta", tänker hon och iakttar sig själv med en dömande blick. Hon uppfattar allt hon är och gör som misslyckat, får okontrollerade gråtattacker och mår allt sämre. Kamraterna tycker att hon beter sig underligt och föräldrarna är oroliga för henne. Modern tar henne med till en psykiater, som dock inte tar henne på allvar. Hon skickas hem med en flaska arsenik- och valerianalösning, som underligt nog ansågs vara lugnande och stärkande. Själv tycker hon att hon är värdelös. "Och vet mig fördenskull vara värd en evig fördömelse." (128) Hon har nått en existentiell nollpunkt.

Men i nästa scen händer något som gör att Malins tanke- och känslovärld i ett enda slag förändras.

Då hon lyfte huvudet efter bönen, fastnade hennes blick i Siv Lindvalls nacke. En fin smärt pelare, som steg ur fulländade halsåsar som en lugn hymn. Och det underliga skedde, att Malins spända och plågade muskler för ett ögonblick slappnade i vila, att de irrande rastlösa ögonen fann ett fäste, att tankarna släppte domen och domnade bort i det befriande vackra linjespelet där framför 
henne. Tankarna, som annars alltid måste tvingas till uppmärksamhet - de behövde inte tvingas här, de var där och stannade utan att kunna slita sig därifrån.

En befrielse. Ett under. (129)

Efter denna upplevelse börjar Malin röra sig bort från den iskallt auktoritära gudstro hon har plågats av. Världen får konturer för henne och livet får mening. Hon börjar utveckla en egen vilja och känner sig alltmer befryndad med Lucifer, den evige upprorsmannen.

Malin kände det som om den halvsmälta ryggraden inom henne drog ihop sig i smärtsam och ändå välgörande kramp, av törst efter stramhet och svikt. Den tvingande kraften, som hon fåfängt hade frågat efter, var där. (198)

Det är på "förälskelsens skapartröskel" allt det nya sker. Liksom i Kellgrens dikt "Den nya skapelsen", en återkommande referens i romanen, förändras hela världen i den älskande människans ögon. Kärleken ger färg och form och skönhet åt naturen. Världen fylls av musik. "Därför att jag har sett dig, Siv." (221) Ändå har ingenting hänt mellan Malin och Siv, ingenting annat än att Malin har blivit huvudlöst förälskad.

Kärleken är obesvarad och en dag förstår Malin att Siv har en pojkvän. "Först kom den enkla och naturliga upptäckten av ett enkelt och naturligt faktum. Där fanns en man, som Siv tyckte om - det borde väl inte vara något överraskande i det." (218) Orden "enkel" och "naturlig" upprepas så att de verkligen står fram i texten och blir till någon form av ironi. Begreppet "natur" var den vetenskapliga retorikens i särklass vanligaste tillhygge när det gällde att mota in folk i heterofållorna. Hela världen må tycka att heterosexualiteten är självklar, men för Malin kommer insikten om att Siv har en pojkvän som en chock. "Hon visste bara ett: att det gjorde ont." (220) Men hon ger inte upp sin nya livskänsla, utan beslutar sig för att strida för den. Hon har blivit en kämpe, en revoltör mot förtryckande föreställningar. Hon börjar identifiera sig med en fattig pojke som tvingas gå och tigga. Han står där på gatan medan höstregnet faller, 
med nakna ben, utan strumpor och skor. Värnlös. Malin jämför kristendomsundervisningens föreställningsvärld med den verklighet pojken lever $\mathrm{i}$.

\begin{abstract}
"Mig skall intet fattas" fick man nog utlägga i rätt abstrakt mening och rätt mycket över ettornas horisont för att det skulle kunna tänkas passa in på Magnus Andersson i något avseende. Hans bara ben i regnet! Hans förkrympta väsen! (224)
\end{abstract}

I den undervisningsplan som Malin förväntas arbeta utifrån står det att han ska lära sig budet om att vara "snäll och lydig". Men ska man verkligen alltid lyda och vara snäll? Malin tvekar. Handlar inte detta bud i stället om att de privilegierade vill behålla sina privilegier?

Det är bara en sak: vad i all föraktad och förtrampad rimlighets namn har detta med sedlighet att göra? Jag skulle vilja kalla det: Läran om de Maktägandes Förbud mot Uppror. Och moral är något annat... (230)

När Malin funderar över pojkens situation drar hon paralleller till sitt eget liv. "Mig skall intet fattas", heter det fast de båda så uppenbart saknar det mest väsentliga. Det talas om både Magnus och Malins "förkrympta väsen". Ett uttryck dyker plötsligt upp i Malins huvud: "Bort med tassarna! Se men inte röra!" Orden kommer till henne när hon ser hur barnen i Magnus klass sitter med händerna knäppta på skolbänkarna framför sig, fast de ostyriga händerna givetvis mycket hellre hade velat leka med något. Men dessa ord är ändå mer relaterade till Malins erfarenhet än till pojkens, eller rättare sagt till det förbud mot erotisk erfarenhet hon lider av. I Magnus fall handlar svårigheterna om att föräldrarna inte ger honom det han behöver vare sig mänskligt eller materiellt. I Malins fall handlar det om att de känslor som skänker innehåll åt hennes inre värld är föraktade och förbjudna i hennes yttre.

Hon tänker sig att det finns ett "hemligt kamratskap" mellan henne och pojken, två människor som far illa. "Han var en liten 
halvt besegrad stridskamrat, som hon ville slåss för så visst som man vill slåss för sig själv." (233) Hon tänker sig att de båda tillhör ett och samma folk, "de olydiga, de upproriska". Hon är beredd att möta det som framtiden har att erbjuda, inte längre med tålig underkastelse utan med egen vilja och strid. Hon är beredd att vinna sitt liv "såsom ett byte". (144)

Ja, så kanske man kan sammanfatta skeendet i romanen. Men de yttre händelserna är bara en liten del av denna flerskiktade roman. Det finns en rad dialoger insprängda i berättelsen där skeendet analyseras och diskuteras. I dessa dialoger aktualiseras de flesta av tidens föreställningar om samkönad kärlek, ibland explicit, ibland mer indirekt. I den första dialogen funderar en medicinare, en teolog och en humanist över hur man ska förstå nevrastenin, den psykiatriska diagnos som Malin har fått. Det som sägs om nevrasteni i denna dialog påminner så mycket om det som brukade sägas om homosexualitet, att begreppen blir överlappande..$^{32}$

Det är Humanisten som framför de nya tankarna. Han argumenterar för att nevrastenin (underförstått den samkönade kärleken) inte kan förklaras av en medicinare eftersom det inte handlar om en sjukdom utan om umgängesvanor och sociala normer. Teologernas moralföreställningar är inte heller till någon nytta, menar han:

Är det inte en förbrytelse egentligen att hämma och skrämma och förvrida det ömtåligaste av allt, det som bara kan utveckla sig självmant som en ömtålig blomma - vår inre etiska (eller om ni så vill vår inre estetiska, eller om ni så vill helt enkelt vår inre hygieniska) väljande instans, vår subtila andliga kärlekskraft hämma och skrämma och förvrida den med bud? (21)

Nästa dialog förs mellan vitt och svart i ett imaginärt makternas schackparti. Svart representerar driftslivet, det vilda, den formlösa och otämjda urkraften, medan Vit är en begränsande, formande princip. Vit säger:

Du hoppas på de giriga händerna? RÖSTEN kuvar dem. Hör du den långsamma metalliska klangen: "Bort med tassarna! Se men 
inte röra!' Då faller händerna maktlösa ner. Deras liv går i ide, de vågar inte vakna. (35)

Svart svarar:

Du känner inte mina vägar. Drömmar vilda som marritter! Hemliga önskningar och fantasier, fulla av raseri och njutning, sådana som hon aldrig skulle våga tala om för en vuxen ... (36)

Svart härskar över krafter som Vit aldrig kan utplåna. Vit svarar:

Men kuva och stänga. Hennes dagar blir kamp mot förbjudna känslor. Om natten sover hon på golvet för att undslippa de förbjudna drömmarna. (38)

Svart kan inte besegras, bara fördröjas, hållas tillbaka lite. Svart säger:

Högst har du kommit till ett nesligt remis - ljudet av ett skott, eller plaskandet, då en kropp faller i vatten, eller de tunga andetagen från en som sover och sover utan att vakna mer. [...] Jag är viljans kärna. Jag är det som driver framåt. Du är hindret och det som håller tillbaka! Du är det sega Nej! Stänger du mig, så rasar jag inåt. Släpp mig lös - så skall jag rubba jorden! Men om du kväver mig - kallar jag dig döden! (38-39)

De förbjudna känslorna kan aldrig arbetas bort, men de kan tryckas undan så obarmhärtigt att det leder till lidande och död. Den abstrakta dialogen mellan Vit och Svart handlar om det som händer inom Malin, där kampen mellan det ostyriga driftslivet och det moralistiska förnuftet utspelas.

Romanens många olika röster ger ord åt motstridiga föreställningar både inom och utanför Malin. I dessa dialoger rör sig berättelsen på en och samma gång inåt i medvetandet och utåt mot Malins och Boyes egen samtid, men också mot andra delar av världen, andra delar av historien och andra föreställningar. 
I en drömscen uppträder personer ur Malins omgivning tillsammans med Lucifer. Malins lärare vill hälsa henne välkommen till Vits sida, till den högstämda idealismen. Men den upproriske skrattar hånfullt:

- Jag påminner er, mina damer och herrar, om den kraft, som överhuvudtaget har lyft min kandidat till dessa höjder och öppnat dessa dörrar för henne. Är församlingen kanske villig att erkänna den kraften som legitim ...?

Ett sus av ovilja gick genom de vita. Sådant talar man inte om, sådant är smaklöst, vi har hört alldeles tillräckligt om sådant i våra dagar. (192)

Före slutscenen, då Malin sitter i seminariets stora sal precis som hon gjorde i inledningsscenen, presenteras en serie uttalanden om henne. De som talar är abstrakta principer som "funktionalist", "estet", "pragmatisk" men också "kvinna med förnuft" och "lärarinna". "Kvinna med förnuft" tycker att Malin var frisk då hon levde i underkastelse inför en dömande Gud och att hon blir sjuk när hon bejakar sina känslor. Att Malin plågas tycker hon bara är som det ska vara. "Och den där förälskelsen, den verkar på mig direkt vedervärdig. Jag är själv så genomsund, så mig äcklar sådant nästan fysiskt." (246) Tonen i romanen är som regel allvarsam, men ibland, som här, finns en strimma av ironisk humor. Något liknande finns i det svar den "förnuftiga kvinnan" får av "lärarinnan" som försvarar Malins svärmeri:

Och den som jag tycker är det mest ideella och rena man kan tänka sig, just därför att den är så lite kroppslig! Tar man den fysiskt, då har man verkligen en dålig fantasi! Sådana skolflickssvärmerier är ju så vanliga så man nästan kan kalla dem normala, och att de inte har ett dugg med kroppen att skaffa, det kan jag garantera, som har sett så mycket sådant i min dar. (246)

Bådas åsikter känns igen från tidigare texter. Den ena talar utifrån någon form av socialdarwinistisk hållning och den andra utifrån den 
romantiska vänskapens kultur. Att sedan en läkare får förklara Malins egenheter med att hon är "degenererad" kompletterar bilden. Alla dessa synsätt är tagna ur den samtid i vilken romanen tillkom. Men det är ingen av dessa röster som får sista ordet, utan en "blid person" som tänker på ett sätt som liknar den rebelliska Malins: "vi måste anförtro oss åt vår längtan. Med rädsla och motstånd finner vi ingenting, inte på någon väg. Med kärlek finner vi allt, på alla vägar." (251)

"Homosexualitet", det ord som vid den här tiden hade blivit den officiella beteckningen för samkönad kärlek, används aldrig i romanen och inga näraliggande ord heller. Detta är givetvis ingen tillfällighet. Orden var helt enkelt så sprängfyllda av heteronormativitet, homofobi och underliga föreställningar att de var oanvändbara för Malin. ${ }^{33}$ När krisen är som värst kämpar hon inte bara med de obändiga känslorna utan också med de svårhanterliga orden.

Jag vill se dig Siv. Jag vill vara där Siv är.

Vad var det! Var det inte - - -

Hon slöt munnen fast till skydd mot alla ord. De förde vilse, hon ville inte veta dem. (136)

Malin bejakar det hon känner för Siv, men inte de ord som brukade användas för att beteckna sådana känslor. Orden för tankarna i fel riktning, de säger något annat än det som Malin upplever. Hon vill inte ens uttala dem.

Ni läppar, kan ni inte sluta er så hårt omkring det osägbara, att inga ord sticker fram sin illvilliga litenhet och grumlar! Stå stilla, tanke, och stör inte, du vet ju inte vad detta är. Det är sådant som sker en gång och aldrig mer i världen. Ge det inget namn, låt det vara som det är, i mitt blod och mina ögon, som liv och sav! Nyskapelsens under behöver inga namn. (139)

Malin fortsätter att vända och vrida på de ord och de tankar som brukar kopplas till samkönad kärlek. Hon vet att det hon upplever inte är så unikt som hon försöker intala sig. Andra människor har upplevt samma sak. Ytterligare andra kommer att göra det. 
Du värjer dig fåfängt, fega kryp!

Sådant som sker en gång och aldrig mer! Tusen gånger tusen gånger har det skett och tusen gånger tusen gånger kommer det att ske! Vet du inte vad det är?

Och krypet vrider sig och stönar, sätter sig upp och måste bekänna: Jag vet det!

$$
\text { Nå - alltså? }
$$

Ja, alltså. Slut. (140)

Att använda ordet "homosexualitet" om sig själv - eller något annat av alla de ord som kunde beteckna människor som förälskar sig i människor av samma kön - är samtidigt att frånkänna sig själv rätten till liv. "Homosexualitet" är helt enkelt inte förenligt med ett värdigt liv. Men Malin stannar inte vid dessa tankar utan börjar kämpa. "Hon ville vinna sitt liv, sitt liv, ingenting annat - såsom ett byte."

Undvikandet av ordet "homosexualitet" handlar alltså inte om att kamouflera det förbjudna, som det gör i några av de andra texterna i den här boken. Absolut inte. Det följer en annan, mycket djärvare litterär strategi. Undvikandet av de kliniska, moraliserande, avståndstagande, föraktfulla och hatiska orden handlar om att skriva om det förbjudna utan att reproducera homofobiska diskurser. Texten plockar sönder normativa tankekonglomerat, såväl kyrkans religiöst motiverade som de förment vetenskapliga besynnerligheter som dominerade tänkandet i berättelsens och skrivandets nu. Romanen river gamla betydelserum för att ge plats för nya tankar och nya känslovärldar.

Det tematiska innehållet i en av de centrala dialogerna - Boye ansåg själv att den var "mycket viktig" - stödjer denna tolkning. ${ }^{34}$ Dialogen har rubriken "Om de fromma ordens betydelse" och förs mellan en munk och hans pater. Det kretsar kring de bibliska orden: "Bokstaven dödar, men anden gör levande." Meningen är hämtad ur Paulus andra brev till korintierna där Paulus kallar församlingen för "ett Kristus-brev", ett brev som är skrivet "icke med bläck, utan med den levande Gudens Ande, icke på tavlor av sten, utan på tavlor av kött, på människohjärtan".35 I dessa ord finns munkens tankar inskrivna. Han talar om avståndet mellan å ena sidan orden för det 
heliga och å andra sidan hur människor förstår dem. Det finns risk att orden stelnar till torra paragrafer, döda dogmer, till fängelser för den levande tron. Han vill lyfta fram den andliga erfarenheten i troslivet och begränsa tilltron till den skrivna textens andliga potential. Givetvis får han svar på tal av patern som talar om relativism och kyrkans undergång, men det är munken, inte patern, som är uttolkare av romanens tendens.

I ett brev till en läsare sammanfattade Boye själv huvudtemat i boken: "vad är moral, på vilken grund bygger den och på vilken borde den bygga?" ${ }^{6}$ Detta är förstås en utmärkt beskrivning av romanens idéinnehåll. Men det finns en ofta citerad passage i Kris som sammanfattar inte bara den tematiska tendensen i romanen utan också den retoriska. Med lyrisk intensitet säger den något som inte kan sägas på något annat sätt än det poetiska.

I natt gick Gud under.

Kanske var det ett tomt namnskal, som gick under.

Men namnskalet drog makter som var dödens. Jag kastar det.

Jag ser tingen. De erkänner inte sina namn. Jag kastar deras namn.

Jag står alldeles ny på stranden av ett hav, och samvetet är inte längre mitt. Jag kastar det.

Viljan till liv har gjort mig naken. Viljan till liv har gjort mig seende. Vad som än kommer skall jag möta med nakna, seende ögon. (145)

Den samkönade kärleken hade i decennier varit den kärlek som inte vågade säga sitt namn. Boye tog frågan vidare. I denna passage tog hon avstånd från de förtryckande orden. Det nya måste mötas med nya ord och nakna ögon.

\section{Slutord}

Liksom Suber och Almqvist avstod Boye från att försöka beskriva vad den samkönade kärleken positivt är. Hon nöjde sig med att avlägsna lager efter lager av det fördomsfulla tankegods som hade 
klistrats på den genom århundradena. I en tid då en del politiker visserligen började gå med på att det kanske inte var så klokt att döma människor till två års straffarbete för samkönad kärlek, men då alternativet att homosexualitet i stället skulle betraktas som en sjukdom genast seglade upp, i en sådan tid var det knappast möjligt att skildra samkönad kärlek på ett fritt och öppet sätt. Inte ens de vanliga orden för homosexualitet och för kvinnor som älskar kvinnor var möjliga att använda. Det fanns så många underliga idéer inskrivna i dessa ord att användningen av dem skulle ha varit att reproducera dem.

Samkönad kärlek och de människor som praktiserar den hade sedan långt, långt tillbaka kopplats till det monstruösa, till överskridandet av gränser som inte fick överskridas - människa/djur, manligt/kvinnligt, vuxen/barn, normalitet/excess, kristet/hedniskt och ibland också liv/död. Det besynnerliga sodomibegreppet är konstruerat av föreställningar om det monstruösa. Kopplingen mellan homosexualitet och sjukdom är också av gammalt datum. Den samkönade sexualiteten tänktes vara orsakad av sjukdom, själv ge upphov till sjukdom och/eller sprida sig som en sjukdom. Den kopplades gärna till dekadens, droger och en urspårad njutningskultur. Och gärna till överklassen. Eller, paradoxalt nog, till vildhet, hedendom och brist på "civilisation". Och till underklassen, de etniskt "andra" och det främmande. Ytterligare en anhopning av associationer handlar om pornografi, prostitution, onani och sexuella excesser.

Många av dessa föreställningar kritiserades av den moderna vetenskap som växte fram mot slutet av 1800 -talet, men dök inte desto mindre upp i konsten och litteraturen flera decennier senare. Ja, de gör så än idag. Under den tid som ligger mellan Frida Stéenhoffs "Det moderna Lesbos" från 180o-talets allra sista år och Karin Boyes Kris 1934 hände det ändå påfallande mycket i dessa frågor. Det skrevs otaliga texter om könsöverskridande och samkönat begär, såväl vetenskapliga och politiska som litterära. Mängder av förklaringsmodeller och begrepp passerade revy - många med rötter i medeltid och biblisk tid, andra nykonstruktioner med kort omsättningstid. Många var uppenbart avsedda att stämpla allt som inte 
passade in i den heteronormativa ordningen som syndigt, brottsligt och förkastligt. Andra ord var förment neutrala men inte desto mindre konstruerade för att urskilja och avskilja - och var de neutrala när de myntades, laddades de som regel med homofobiska innebörder så fort de började användas i den offentliga diskussionen.

Samtidigt med alla dessa diskursiva förändringar växte det fram en livaktig och mångfacetterad gaykultur i Europas storstäder där nya tankar, nya roller, nya identiteter och nya ord skapades. Utan sin kännedom om gaykulturen, både den i Berlin och den i Stockholm, hade Boye knappast kunnat skriva Kris. I denna kultur fanns den kritiska blick på den rådande heteronormativa ordningen som hon skrev in i sina texter.

Det alternativ hon ger till alla de lagar, regler, institutioner, teorier, kategorier, roller, föreställningar, värderingar och begrepp som marginaliserar den samkönade kärleken är enkelt och vackert: Vi måste anförtro oss åt vår längtan. 